\title{
Análise do conhecimento de professores acerca da conceituação de letramento
}

\author{
Claudiane Hornes Ferrari Antunes de Souza ${ }^{1}$
}

Souza CHFA. Análise do conhecimento de professores acerca da conceituação de letramento [dissertação]. Curitiba, Faculdade de Ciências Biológicas da Saúde da Universidade Tuiuti do Paraná; 2008.

Esta dissertação tem como objetivo analisar o conhecimento de um grupo de professores acerca da conceituação de letramento, bem como as práticas pedagógicas desses profissionais relacionadas a tal conceito. Discute as tendências pedagógicas liberais e progressistas com enfoques na concepção de linguagem de cada tendência, na relação professor/aluno e nas práticas desenvolvidas relacionadas à apropriação de linguagem escrita; aborda também a formação dos professores das séries iniciais do ensino fundamental e os Parâmetros Curriculares Nacionais da língua portuguesa. Trata das relações e diferenças entre letramento e alfabetização e dos usos de práticas sociais que envolvem a leitura e a escrita. A pesquisa de campo foi realizada junto a 100 professores das $1^{\mathrm{a}}$ e $2^{\mathrm{a}}$ séries do Ensino Fundamental, todos da rede pública. Para a coleta de dados, primeiramente, realizou-se um questionário com questões voltadas à identificação e formação acadêmica dos respondentes, questionamentos sobre o entendimento de linguagem escrita $\mathrm{e}$ seu processo de apropriação, conhecimento de alfabetização e letramento como também as práticas pedagógicas desenvolvidas na perspectiva do letramento. Com base nas respostas fornecidas pelos professores, podemos afirmar que apenas $12 \%$ demonstram algum entendimento sobre letramento. A grande maioria, $87 \%$, ainda não apresenta conhecimento sobre o termo letramento, apesar de $74 \%$ dos respondentes relatarem já ter lido sobre o tema e de $60 \%$ afirmarem ter frequentado eventos que tratam do assunto. Quanto às práticas pedagógicas desses professores, $86 \%$ deles afirmam desenvolver atividades que visam o letramento; porém, tais afirmações devem ser analisadas na medida em que o entendimento dos professores sobre a linguagem e seu processo de aprendizagem não dão conta de uma prática com a leitura e com a escrita em uma perspectiva de letramento.

Trabalho realizado na Universidade Tuiuti do Paraná para obtenção do título de Mestre em Distúrbios da Comunicação, sob orientação da Profa. Dra. Giselle Aparecida de Athayde Massi.

(1) Mestre, Professora do Colégio Estadual Ivanete Martins de Souza - São José dos Pinhais (SP), Brasil.

Endereço para correspondência: Claudiane Hornes Ferrari Antunes de Souza. R. Carlos Drumond de Andrade, 440, São José dos Pinhais (SP), Brasil, CEP: 83321-30. 